\title{
Electrical system design of solar powered electrical recreational boat for Indonesian waters
}

\author{
Sunaryo Sunaryo ${ }^{1, *}$, and Adri Wirawan Ramadhani ${ }^{2}$ \\ ${ }^{1}$ Naval Architecture and Marine Engineering Study Program, Department of Mechanical Engineering, Universitas Indonesia, Depok, \\ 16424 , Indonesia \\ ${ }^{2}$ Naval Architecture and Marine Engineering Study Program, Department of Mechanical Engineering, Universitas Indonesia, Depok, \\ 16424, Indonesia
}

\begin{abstract}
Indonesia has more than 17,000 islands and has plenty of beautiful beaches and underwater spots which have great potential for maritime tourism. Tourism was ranked 3rd on Indonesia's foreign income and plays an important role for the country's ecomony. Despite having potential advantages, the government has not yet maximized its efforts to develop the attractiveness of its maritime tourism. Beside the beautiful spots Indonesia is also blessed with all year long sun shine, which could be tapped as renewable and green energy as substitution to fossil fuel. Refer to these great advantages of natural resources the research was aimed to support the government's program in developing its maritime tourism and to promote the use of green and renewable energy by designing a solar-powered tourism recreational boat which has 12 meters of length. The paper is focused on the design of solar energy and its electrical system, which includes conversion of solar energy to electrical energy and store it in the battery, the required electrical power is also predicted based on the appliances and equipment installed in the boat, the optimum attachment of solar panels on the boat structure is also calculated. All the methods and information we use are obtained from literature study, discussion with experts, and surveys to Jagur as solar-powered electric boat from Universitas Indonesia.
\end{abstract}

\section{Introduction}

Located in the topical area and equatorial line, Indonesia has huge source of renewable energy in the form of sunlight. The total region of Indonesia is 5,193,252 km2, consisting of $65 \%$ water and a total of 18,100 islands. Natural resource is also one of Indonesia's charms, with beautiful islands like Bali and Lombok; tourists tend to enjoy the climate and scenery of endless beaches and mountains. Approximately 500,000 international tourists travel to Bali monthly [1]. However, most of the transportation modes in Indonesia are still based on conventional energy resources. The ferry or boats used to travel through the islands are still using oil. It is mandatory for Indonesia to move to the renewable energy area to reduce global warming while increasing the financial potential of tourism.

Along with the government's marine transportation directorate strategic plan to reduce the greenhouse effect by $26 \%$ by 2020 [2], this research is aimed to design an eco-friendly tourism boat that uses sunlight as its main fuel for the solar array. The electricity produced by the solar array is stored temporarily in the lithium batteries system, which then will be used to propel the boat using the electric motor and propeller. There are a couple of paper that discussed this topic, one of which is a tourism boat design that is equipped with two $8 \mathrm{~kW}$ and managing to achieve $11 \mathrm{MWh}$ of electricity yearly [3]. This paper is focused on the 12-meter recreational boat's design of solar energy and its electrical system, which includes conversion of solar energy to electrical energy and store it in the battery, the required electrical power is also predicted based on the appliances and equipment installed in the boat, the optimum attachment of solar panels on the boat structure is also calculated. All the methods and information we use are obtained from literature study, discussion with experts, and surveys to Jagur as solar-powered electric boat from Universitas Indonesia.

\section{Methodology}

The recreational boat for Indonesian waters we designed has the following characteristics:

- Hull form is catamaran

- Length Perpendicular: $12.13 \mathrm{~m}$

- Length Overall:12.64 m

- Breadth on midship: $5.39 \mathrm{~m}$

- Draft: $0.7 \mathrm{~m}$

- Cruising duration: 4 hours (maximum)

- Maximum speed: 6 knots $(\sim 11 \mathrm{~km} / \mathrm{h})$

- Cruise speed: 4 knots $(\sim 8 \mathrm{~km} / \mathrm{h})$

\footnotetext{
Corresponding author: naryo@eng.ui.ac.id
} 
We chose catamaran hull form since it will deliver more area on top of deck to mount the photovoltaic array. On the design of this boat, the roof of the superstructure has $12 \mathrm{~m}$ length and 4,89 $\mathrm{m}$ in width with the total area available to be mounted by photovoltaic array is $58,62 \mathrm{~m} 2$.

The boat is intended to be used for recreational and tourism purposes on Indonesian waters surrounding the remote islands. With the given characteristics, we can estimate the cruising range of around $31 \mathrm{~km}$ for each trip. It is sufficient to make a scenic tour around Raja Ampat Islands, Komodo Island, Alor Island, Padar Island, and a short scenic route in Bali or Lombok coastline.

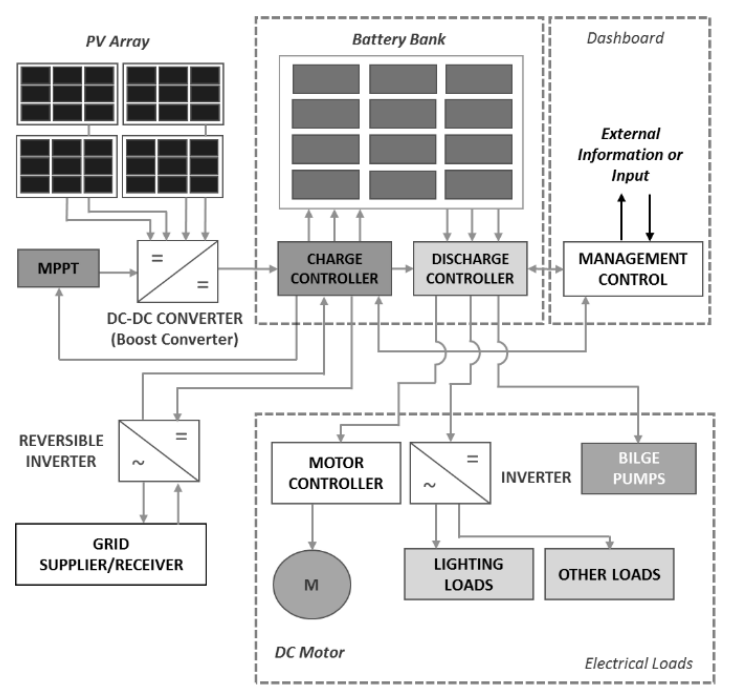

Fig. 1. The boat's electrical system topology

3 Results and Discussion

3.1 Electrical Load Calculation
Electrical loads onboard the boat can be classified into three groups, such as: mechanical, lighting, and others. Mechanical group consist of the DC onboard motor, bilge pumps, and various electrical control panels. Lighting group consist of lamps and accent lights that will illuminate the boat on night. To measure the total electrical load, it is imperative to understand the specifications of every appliance. To calculate the load, the below equations are available.

$$
\begin{aligned}
& P_{T}=P x t \\
& P_{T}=V x C
\end{aligned}
$$

In the equation, $\mathrm{P}_{\mathrm{T}}$ is the electrical load in a given amount of time (Wh), $\mathrm{P}$ is the wattage of the appliance $(\mathrm{W}), \mathrm{t}$ is the operating time $(\mathrm{h}), \mathrm{V}$ is the rated voltage of the appliance (V), and $\mathrm{C}$ is the capacity (Ah). A correction factor of $15 \%$ is also imperative to be included in the calculation. The estimated loads for each appliances on board is identified on Table 1 .

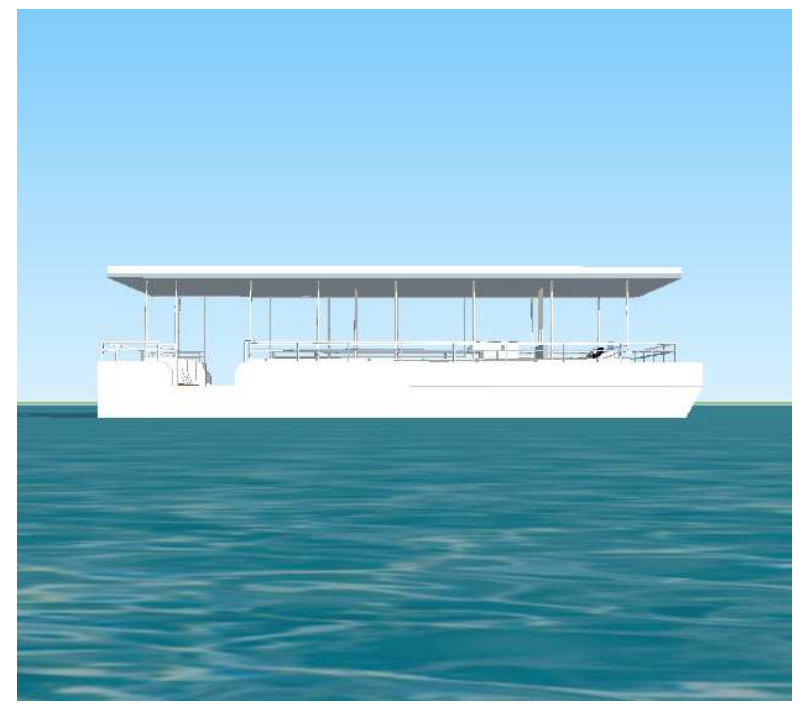

Fig. 2. The boat's design

\begin{tabular}{|c|c|c|c|c|c|c|}
\hline NO & GROUP & COMPONENTS & $\begin{array}{l}\text { POWER } \\
\text { (WATT) }\end{array}$ & $\begin{array}{c}\text { VOLTAGE } \\
\text { (V) }\end{array}$ & $\begin{array}{c}\text { QUAN-TITY } \\
\text { (PCS) }\end{array}$ & $\begin{array}{c}\text { TOTAL } \\
\text { LOADS } \\
\text { (WATT) }\end{array}$ \\
\hline 1 & \multirow{3}{*}{ LIGHT } & Accent Light (Outside) & 4 & 12 & 15 & 60 \\
\hline 2 & & Underwater Light & 26,4 & 24 & 2 & 52,8 \\
\hline 3 & & LED Lamp (Inside) & 12 & 220 & 12 & 144 \\
\hline 4 & \multirow{5}{*}{$\mathrm{MECH}$} & $\begin{array}{l}\text { Electric Motor (Golden } \\
\text { Motor) }\end{array}$ & 4902 & 48 & 1 & 4902 \\
\hline 5 & & Bilge Pump & 30 & 12 & 2 & 60 \\
\hline 6 & & Battery Cooler (Fan) & 70 & 220 & 4 & 280 \\
\hline 7 & & Navigation Panel & 8 & 24 & 1 & 8 \\
\hline \multirow[t]{2}{*}{8} & & Control Panel & 5 & 24 & 1 & 5 \\
\hline & & Total & 5057,4 & & 38 & 5511,8 \\
\hline
\end{tabular}

Table 1. Electrical Appliances Specification 


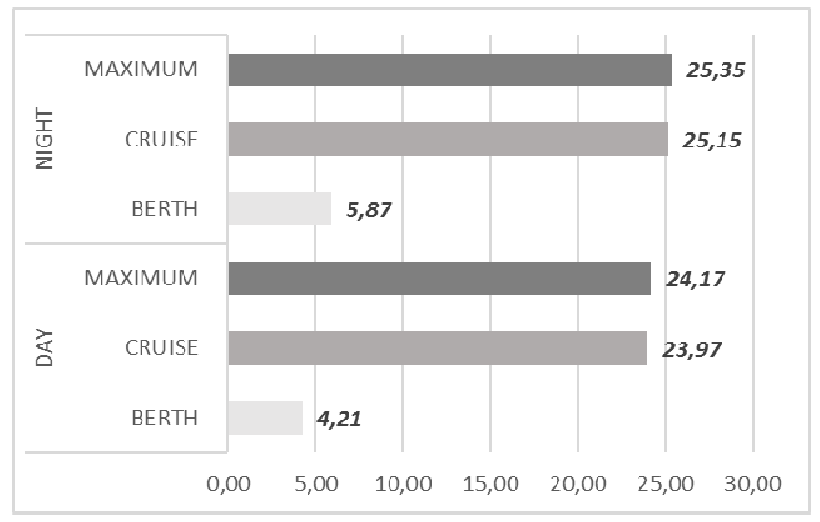

Fig. 3. Electrical load in each condition

Electrical load balance is the equilibrium between load and power generation. Since not every appliance on the boat is working 24/7. It is imperative to estimate the boat electrical loads in certain conditions, such as when the boat berths, cruise, and maximum condition. It also includes the difference in operating time, whether it's daytime or nighttime. Based on the results from Figure 2 , the maximum condition load for each voyage is 25.35 $\mathrm{kWh}$ on nighttime and $24.17 \mathrm{kWh}$ on daytime. The maximum load is then used to calculate the battery system and photovoltaic arrangement

\subsection{Battery System}

Battery is used to store the electricity produced by photovoltaic panels to power the appliances onboard the boat. Battery system consists of several battery packs connected in series and/or parallel connections. Series connected battery pack total voltage will be the sum of each battery packs voltage. While parallel connected batteries total capacity (Ah) supplied will have be the sum of each battery packs capacity. Batteries can also be combined with several battery connections to achieve a required voltage or capacity, such as $2 \mathrm{~S} 2 \mathrm{P}$ meaning that 2 parallel connected batteries is then connected to another 2 parallel connected battery through a series connection.

For our project, we have chosen the SUN 25695 battery packs with the specifications shown on Table 2.

Based on the calculation of electrical load, we need to supply a maximum energy of $25.35 \mathrm{kWh}$ for the remainder of the cruise time $(4 \mathrm{~h})$. To achieve the required power, we also need to consider the efficiency and Depth of Discharge (on about $80 \%$ ) of the battery system. The required voltage is $48 \mathrm{~V}$, in accordance to the voltage DC motor and bilge pumps. From the calculations on Table 3, we decided a battery system consisting of 4 battery banks (parallel) with each bank consisting 4 battery packs connected series, to achieve the $48 \mathrm{~V}$ and $33.46 \mathrm{kWh}$ load requirements.
Table 2. Battery Specification

\begin{tabular}{|c|c|}
\hline \multicolumn{2}{|c|}{ Specifications of SUN 26650 Battery model } \\
\hline Normal Capacity & $200 \mathrm{Ah}$ \\
\hline Voltage Nominal & $12,8 \mathrm{~V}$ \\
\hline Weight & $26 \mathrm{~kg}$ \\
\hline Dimension & $500 \times 235 \times 225 \mathrm{~mm}$ \\
\hline Standard Discharge $\left(\mathrm{V}_{\mathrm{co},} \mathrm{I}_{\mathrm{d}}\right)$ & $8 \mathrm{~V}, 50 \mathrm{~A}$ \\
\hline Standard Charge $\left(\mathrm{V}_{\mathrm{c}}\right)$ & $14.6 \mathrm{~V}$ \\
\hline DC internal resistance & $50 \mathrm{~m} \Omega$ \\
\hline
\end{tabular}

Table 3. Battery System Calculation

\begin{tabular}{|l|l|l|}
\hline Property & Value & Unit \\
\hline Maximum Load & 25.35 & $\mathrm{kWh}$ \\
\hline Power (10\% Efficiency) & 27.88 & $\mathrm{kWh}$ \\
\hline Total Power (DoD) & 33.46 & $\mathrm{kWh}$ \\
\hline Required Voltage & 48 & $\mathrm{~V}$ \\
\hline n Series & 4 & $\mathrm{pcs}$ \\
\hline n Parallel & 4 & $\mathrm{pcs}$ \\
\hline Battery Capacity & 800 & $\mathrm{Ah}$ \\
\hline \multirow{2}{*}{ Total Capacity } & 38,400 & $\mathrm{Wh}$ \\
\cline { 2 - 3 } & 38,4 & $\mathrm{kWh}$ \\
\hline Batteries Needed & 16 & $\mathrm{pcs}$ \\
\hline \multirow{2}{*}{ System Weight } & 416 & $\mathrm{~kg}$ \\
\cline { 2 - 3 } & 0.4 & $\mathrm{tons}$ \\
\hline
\end{tabular}

\subsection{Photovoltaic Power Generation System}

In order to measure the potential photovoltaic power generation, it is imperative to estimate the available space for solar array arrangement on the roof of the boat. In this project, we use JSkye flexible solar panel model ST44M 140-FLP solar module; every panel has dimensions of $1.435 \mathrm{~mm} \times 540 \mathrm{~mm} \times 15 \mathrm{~mm}$, maximum power voltage (Vmp) $24.2 \mathrm{~V}$, maximum power current 
(Imp) $5.8 \mathrm{~A}$, with maximum output power (WPmax) of $140 \mathrm{~W}$. According to the boat design, the available space is $58, .68 \mathrm{~m} 2$, hence the possible solar module to be mounted on the roof is 58 units, with series configuration.

$$
W_{N}=W_{P \max } x \eta_{p}
$$

We can estimate the photovoltaic array energy output at standard radiation by using equation 3 , with WPmax is the maximum watt peak produced by the panel and $n p$ is the number of panels installed, Resulting in 8,1 kWPmax. The yearly average electrical energy from photovoltaic array can be estimated by the following equation [3].

$$
P_{D C}=Q_{m} \times W_{N} \times K_{1} \times K_{2} \times K_{3} \times K_{4}
$$

- $P_{D C}$ is the photovoltaic energy $(\mathrm{kWh} /$ year $)$

- $\mathrm{W}_{\mathrm{N}}$ is the photovoltaic array energy output at standard radiation (kWPmax)

- $\mathrm{Q}_{\mathrm{m}}$ is the yearly average flux of solar radiation; in this paper we consider a global horizontal irradiation of $1500 \mathrm{kWh} / \mathrm{m} 2 /$ year.

- $\mathrm{K}_{1}$ is the coefficient for compensation of temperature effect. Operating temperature increases when a series of solar panels placed under the Sun. When the operating temperature rises, power output down (due to the characteristics of the material of the panel). Our approximation of $\mathrm{K}_{1} \approx 0.9$.

- $\mathrm{K}_{2}$ is the coefficient for compensation coefficient of stain and wear on the circuit. Our approximation $\mathrm{K}_{2}$ $\approx 0.9$.

- $\mathrm{K}_{3}$ is the coefficient of the energy loss coefficient on DC circuits. Solar panel systems generally have several cables to connect to each module, and the number of connections it creates some obstacles in the flow of electricity, which reduces the total power output of the system. Our approximation of $\mathrm{K}_{3} \approx 0.95$.

- $\mathrm{K}_{4}$ is the energy loss coefficient in DC-DC converter, this tool is used to change the voltage of the solar panel to the battery to be used by the boat appliances. Our approximation of $\mathrm{K}_{4} \approx 0.95$.

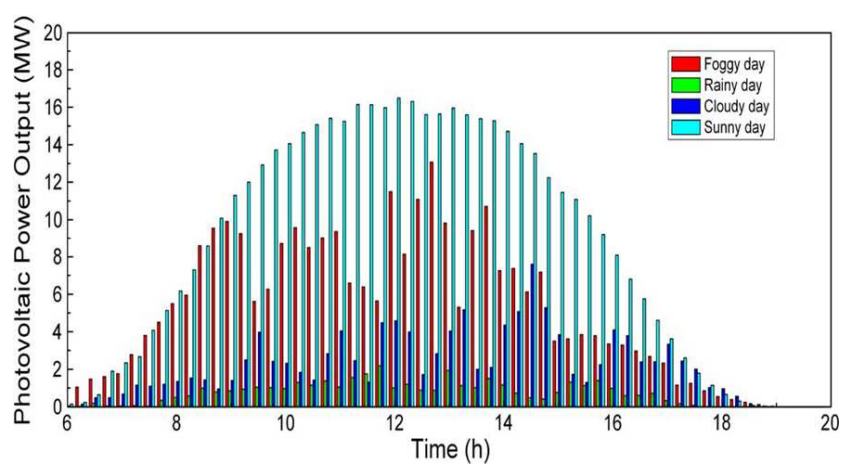

Fig. 4. PV power output on different weather conditions [8]

According to the calculation on Table 3, the JSkye ST44M 140-FLP solar array will be able to produce electricity for $8.89 \mathrm{MWh}$ yearly, and approximately about $24.38 \mathrm{kWh}$ daily.

This calculation is only intended for sunny weather condition, where the irradiation levels are on the best condition. On other weather conditions, such as cloudy, foggy, or rainy, the photovoltaic array performance would be reduced considerably as indicated in fig. 4: [8].

Table 4. Reduction Factors on PV System

\begin{tabular}{|l|r|}
\hline \multicolumn{2}{|c|}{ REDUCTION FACTORS } \\
\hline Foggy & $40 \%$ \\
\hline Cloudy & $70 \%$ \\
\hline Rainy & $92 \%$ \\
\hline
\end{tabular}

Based on the result from Table 4, we can infer that due to weather conditions, there will be reduction in PV performance as follows: the reduction factors on foggy weather is $40 \%$, cloudy $70 \%$, and rainy is $92 \%$. The considerably high reduction factors will have a big effect on the ship's operationality. Table 5 indicated the estimation of power output in different weather conditions. We can infer that on rainy weather, the PV system can only produce $1.95 \mathrm{kWh}$ daily.

Table 5. Daily Power Output on Different Weather Conditions $(\mathrm{kWh})$

\begin{tabular}{|l|l|r|}
\hline \multirow{4}{*}{$\begin{array}{l}\text { Daily } \\
\text { Power } \\
\text { Output }\end{array}$} & Sunny & 24.38 \\
\cline { 2 - 3 } & Foggy & 14.63 \\
\cline { 2 - 3 } & Cloudy & 7.31 \\
\cline { 2 - 3 } & Rainy & 1.95 \\
\hline
\end{tabular}

Table 6. Photovoltaic System Summary

\begin{tabular}{|l|l|l|}
\hline Property & Value & Unit \\
\hline Available Space & 58.68 & $\mathrm{~m} 2$ \\
\hline Total Solar Panel & 58 & $\mathrm{pcs}$ \\
\hline Yearly Power Output & 8.89 & $\mathrm{MWh}$ \\
\hline Daily Power Output & 24.38 & $\mathrm{kWh}$ \\
\hline
\end{tabular}

The above calculation (Table 6) proves that on sunny weather, the photovoltaic array will be able to sustain the boat's maximum power need for a single daytime trip. (Maximum boat power need on daytime is $24.17 \mathrm{kWh}$ ), but not fully capable of sustaining a trip on night time. 


\subsection{Power Management}

Based on the calculation, we can summarize the outputs of each calculation in Table 7 below.

Table 7. Electrical System Summary

\begin{tabular}{|l|l|}
\hline Property & Value (kWh) \\
\hline Maximum Load (Night) & $25.35 \mathrm{kWh}$ \\
\hline Maximum Load (Day) & $24.17 \mathrm{kWh}$ \\
\hline PV Power Output (Daily) & $24.38 \mathrm{kWh}$ \\
\hline Battery Capacity & $38.40 \mathrm{kWh}$ \\
\hline
\end{tabular}

From the results in Table 7, we can infer that the PV array power output cannot fully supply the maximum electrical load in night time, therefore the boat will rely on the fully charged battery (pre-charged while the boat berths) to accommodate the electrical needs onboard. Moreover, since sunlight is considered an intermittent power source, there must solution to accommodate the electrical needs onboard the boat when the weather is bad or when there will be more than one trip on one day.

During the day, the charging processes involving PV array and the battery. But on night time, when there is no more sunlight, the boat electrical appliances rely completely on the battery system. Therefore, it is important to make sure that the battery system can deliver the loads perfectly.

One of the solutions is to fully load the battery and prepare spare battery banks. The batteries system can be charged when the boat is not operational, making the spare batteries fully charged is important to make multitrip available for this recreational boat. The owner should prepare a charging station for the batteries on board or the spares. On the off day, when the boat is not used by the owner, the photovoltaic array may be used to power electricity for the grid or supporting the electrical needs for the building near the boat's location.

In order to measure the potential photovoltaic power generation, it is imperative to estimate the available space for solar array arrangement.

\section{Conclusion}

Solar-powered recreational boat electrical system consists of three main systems, i.e. photovoltaic panel system, battery system, as well as the installation of electrical equipment inside. Solar panel system that is placed above the ship restaurant consists of $58 \mathrm{PV}$ modules from Jskye, with each having maximum power (Wp) of 140 Watts. According to the data processing and analysis of solar array system, the electrical power that can be generated with solar panel system is $24.38 \mathrm{kWh}$ per day.

For the battery, we used 16 pcs of SUN 26650 , assembled in 4 banks of batteries connected in series and parallel (4S4P). The battery systems can sustain electricity up to $33.46 \mathrm{kWh}$. The resulting electrical power solar panel is stored in a battery for use by electrical equipment inside the vessel. The electrical power required for each trip is $24.17 \mathrm{kWh}$. It is understood that there will be excess electrical power to be generated by the two systems above. However, if there is more than one trip in each day, or there are bad weather conditions, then we needed a battery backup or charging station on the ground to support the electrical needs onboard.

\section{Acknowledgement}

The Authors would like to thank Directorate of Research and Community Engagement Universitas Indonesia for providing fund for finalizing the research and publishing its results through PITTA Project 2018 Contract number 2541/UN2.R3.1/HKP.05.00/2018; Thanks also expressed to Solar Boat Team Universitas Indonesia 2018 who will participate in Solar Sport One Competition in the Netherlands that provide us with significant data and experiences to work on this research, and for every party that support the development of this research.

\section{References}

1 Kementrian Pariwisata Data Kunjungan Wisatawan Mancanegara Bulanan Tahun 2017

2 Direktorat Jenderal Perhubungan Laut Rencana Strategis Direktorat Jenderal Perhubungan Laut Tahun 2015-2019 192

3 Spagnolo G S, Papalillo D, Martocchia A and Makary G 2012 Solar-Electric Boat Journal of Transportation Technologies 02 144-9

4 Hersch P and Zweibel K 1982 Basic photovoltaic principles and methods

5 Hantula R 2010 How do solar panels work? (New York, NY: Chelsea Clubhouse)

6 Adityawan E 2010 Studi Karakteristik Pencatuan Solar Cell Terhadap Kapasitas Penyimpanan Energi Baterai 85

7 Winter M and Brodd R J 2004 What Are Batteries, Fuel Cells, and Supercapacitors? Chemical Reviews 104 4254-8

8 Shi, J., Lee, W.-J., Liu, Y., Yang, Y., \& Wang, P. (2012). Forecasting Power Output of Photovoltaic Systems Based on Weather Classification and Support Vector Machines. IEEE Transactions on Industry Applications, 48(3), 1064-1069.

9 Markvart, T. (1994). Solar Electricity. Chicester, U.K.: John Wiley \& Sons.

10 Messenger, R. A., \& Ventre, J. (2004). Photovoltaic systems engineering (2nd ed). Boca Raton: CRC Press.

11 Taylor-Moon, P. D. E. J. (2013). Convertor and Invertor Technologies. Alabama University of Engineering. 